\title{
Intense craving for appetizing foods: validation and standardization of the Food Cravings Questionnaire-Trait in Mexico
}

\author{
María Delfina Marín-Soto, ${ }^{1}$ Cruz Vargas-De León, ${ }^{1}$ Nadia Mabel Pérez-Vielma, ${ }^{2}$ \\ Margarita Castillo-Ramírez, ${ }^{3}$ Ángel Miliar-García, ${ }^{2}$ María Magdalena Murillo-Tovar, ${ }^{2}$ \\ Bárbara Méndez-Peña² and Víctor Aguilera-Sosa ${ }^{2 *}$ \\ ${ }^{1}$ Instituto Politécnico Nacional, Higher School of Medicine; 'Instituto Politécnico Nacional, Interdisciplinary Center of Health Sciences, Santo Tomás \\ Unit; ${ }^{3}$ Mexico City's Ministry of Health. Mexico City, Mexico
}

\begin{abstract}
Introduction: Food craving is a motivational and physiological response for eating specific foods, mainly with high caloric content. To assess food craving, the Food Cravings Questionnaire-Trait, which is a multi-dimensionally structured instrument that has been validated in several countries and has been shown to be sensitive and adaptable to contextual-cultural changes, is used among others. Objectives: To validate and standardize the Food Cravings Questionnaire-Trait in adults of Mexico City. Method: Non-experimental, cross-sectional, randomized study of 1059 subjects of both genders, between 18 and 84 years of age; $71.86 \%$ of the female gender. Psychometric properties were examined with exploratory and confirmatory factor analyses. Results: The domains of the questionnaire were reduced and the items were reorganized differently with regard to the original version. The confirmatory factor analysis showed an adequate fit and acceptable standardization of factors. High internal consistency was found for the global questionnaire $(\alpha=0.973$ and rho $=0.975)$ for each one of the domains. Conclusion: This study determines the viability of the Food Cravings Questionnaire for the population of Mexico City.
\end{abstract}

KEY WORDS: Food Craving. Alimentary behavior. Food Cravings Questionnaire-Trait.

\section{Deseo intenso por alimentos apetecibles: validación y estandarización del Food Craving Questionnaire-Trait en México}

\section{Resumen}

Introducción: El food craving o "ansia por comer" es una respuesta motivacional y fisiológica por comer alimentos específicos, principalmente con alto contenido calórico. Para evaluarlo se usa, entre otros, el Food Craving Questionnaire Trait, estructurado multidimensionalmente y validado en diversos países, el cual ha mostrado ser sensible y adaptable a los cambios contextuales-culturales. Objetivos: Validar y estandarizar el Food Craving Questionnaire-Trait en adultos de la Ciudad de México. Método: Estudio no experimental, transversal y aleatorizado de 1059 sujetos de uno y otro sexo, entre 18 y 84 años; 71.86 \% del sexo femenino. Se examinaron propiedades psicométricas con análisis factoriales exploratorios y confirmatorios. Resultados: Se redujeron los factores del cuestionario y los ítems se reorganizaron de forma diferente al original. El análisis factorial confirmatorio mostró ajuste adecuado y estandarización aceptable de los factores. Se encontró alta consistencia interna para el cuestionario global $(\alpha=0.973$ y rho $=0.975)$ para cada uno de los factores. Conclusión: Este estudio determina la viabilidad del Food Craving Questionnaire para población de la Ciudad de México.

PALABRAS CLAVE: Ansia por comer. Conducta alimentaria. Food Craving Questionnaire-Trait.

Correspondence:

*Víctor Ricardo Aguilera-Sosa

E-mail: psicologiaonline117@gmail.com

0016-3813/○ 2019 Academia Nacional de Medicina de México, A.C.. Published by Permanyer. This is an open access article under the CC BY-NC-ND license (http://creativecommons.org/licenses/by-nc-nd/4.0/).

Date of reception: 21-06-2019

Date of acceptance: 01-07-2019 


\section{Introduction}

The presence of food, the environment, ${ }^{1}$ culture and learning are related to the decision on what a subject will eat; ${ }^{2-4}$ desire, choice, quantity and frequency are related to the inability to inhibit ingestive behavior. It has been hypothesized that it is related to over-ingestion of foods with high caloric content, a behavior similar to that of addicted subjects. ${ }^{5}$

Food craving (FC) is a physiological and behavioral response ${ }^{6}$ that triggers intense desire, very difficult to resist, ${ }^{7}$ for eating specific foods, ${ }^{8}$ particularly those with high caloric content. Due to its proximity to addiction, FC is described as a comorbid factor of eating disorders, overweight and obesity. ${ }^{6,9,10}$

Cepeda Benito, Gleaves, Williams and Erath ${ }^{11}$ developed the Food Cravings Questionnaire-Trait (FCQ-T), a multifactorial questionnaire that encompasses behavioral, cognitive, emotional and physiological components, with $\alpha=0.97$, composed of nine factors:

- An intention and planning to consume food.

- Anticipation of positive reinforcement that may result from eating.

- Anticipation of relief from negative states and feelings as a result of eating.

- Possible lack of control over eating if food is eaten.

- Thoughts or preoccupation with food.

- Craving as a physiological state.

- Emotions that may be experienced before or during food cravings or eating.

- Environmental cues that may trigger food cravings.

- Guilt that may be experienced as a result of cravings and/or giving into them.

It consists of 37 items, where the frequency the "craving" occurs with is shown, as determined with a Likert scale: never (1), rarely (2), sometimes (3), often (4), almost always (5) and always (6).

Avitia et al. ${ }^{12}$ used the original versions of the FCQ-T and Food Cravings-State to measure it in the Mexican population; however, they were not validated, in addition to not explaining the application procedure. Therefore, the results of that research are questionable.

Due to the combined prevalence of overweight and obesity in Mexico and given that FC is an important component of addiction to sugary and fatty foods, it is imperative to assess it in the Mexican population.
The purpose of this work was to validate and standardize the FCQ-T in Mexico City adult subjects.

\section{Method}

Non-experimental, cross-sectional and randomized study of 1059 adults attending the jurisdictions of the Ministry of Health of Mexico City, who were between 18 and 83 years of age and who read and signed the informed consent. The FCQ-T was used in the Spanish version, and the $R$ Statistical Software, version 3.4.4, was used for statistical analysis.

A pilot test was conducted at the Lázaro Cárdenas Unit of the National Polytechnic Institute, with a convenience sample of 50 subjects, who were asked to comment on the wording. Reliability analysis was performed, the wording was adapted to Mexican regionalisms and another group was asked to answer the revised questionnaire. Subsequently, the Miguel $\mathrm{Hi}-$ dalgo, Azcapotzalco, Cuauhtémoc and Álvaro Obregón jurisdictions of the Ministry of Health of Mexico City were randomized and the questionnaire was applied to 1059 adults of either gender, who attended medical appointments; they were asked to voluntarily participate and to sign the informed consent.

Statistical analyses were carried out with R Statistical Software, version 3.4.4 (R psych1 ${ }^{3}$ and lavaan packages) ${ }^{14}$ looking for significance at $p<0.05$.

FCQ-T validity was verified by exploratory and confirmatory factor analyses. Item normality was considered acceptable for asymmetric values between - 0.5 and 0.5 , and kurtosis between -2 and 2. We used the Kaiser-Meyer-Olkin value and Bartlett's test of sphericity for adequacy of data for the factor analysis; Kaiser-Meyer-Olkin values $<0.6$ indicated inadequate sampling. ${ }^{15}$ Exploratory factor analysis with Promax oblique rotation was applied. To create an FCQ-T property, items were extracted for each factor if they were loaded at $\geq 0.35$ in a particular factor, but $\geq 0.35$ in the others.

Subsequently, in the confirmatory factor analysis model, the robust maximum likelihood estimator was used, which provides standard errors/robust adjustment indices in the nature of the Likert scale items and non-normality.

To assess that the model would fit, the comparative fit index (CFI), the Tucker-Lewis index (TLI), the standardized root mean square residual (SRMR), and the root mean square error of approximation (RMSEA) were used. 
Gaceta Médica de México. 2020;156

Table 1. Exploratory and confirmatory factor analysis

\section{Factors and items}

\begin{tabular}{|l|c|c|c|c|c|}
\hline \multicolumn{3}{|c|}{ EFA } & \multicolumn{2}{c|}{ CFA } \\
\hline ARE & PR & LC & PE & SFL & $95 \%$ Cl \\
\hline
\end{tabular}

17. Cuando como algo que deseo con intensidad me siento culpable (When I eat what I am craving I feel guilty about myself)

20. Siento deseos de comer cuando estoy aburrido (a), enfadado (a), o triste (I crave foods when I feel bored, angry, or sad)

21. Después de comer no tengo tanta ansiedad (I feel less anxious after I eat)

25. No tengo la fuerza de voluntad de resistir mis deseos de comer lo que se me antoja (I have no will power to resist my food crave)

26. Una vez que me pongo a comer algo tengo problemas para dejar de hacerlo (Once I start eating, I have trouble stopping)

27. Por mucho que lo intento, no puedo parar de pensar en comer (I can't stop thinking about eating no matter how hard I try)

28. Gasto demasiado tiempo pensando en lo próximo que voy a comer (I spend a lot of time thinking about whatever it is I will eat next)

29. Si me dejo llevar por la tentación de comer, pierdo todo el control (If I give in to a food craving, all control is lost)

30. A veces me doy cuenta de que estoy soñando despierto y estoy fantaseando con comer (I daydream about food)

31. Cada vez que se antoja una comida sigo pensando en comer hasta que como lo que se me antojó (Whenever I have a food craving, I keep on thinking about eating until I actually eat the food)

32. Cuando tengo muchas ganas de comer algo estoy obsesionado con comer lo que deseo (If I am craving something, thoughts of eating it consume me)

33. A menudo deseo comer cuando siento emociones fuertes (My emotions often make me want to eat)

34. Cada vez que voy a un banquete termino comiendo más de lo que necesito (Whenever I go to a buffet, I end up eating more than what I needed)

35. Para mí es difícil resistir la tentación de tomar comidas apetecibles que están a mi alcance (It is hard for me to resist the temptation to eat appetizing foods that are in my reach)

36. Cuando estoy con alguien que se excede comiendo, yo también me excedo (When I am with someone who is overeating, I usually overeat too)

\begin{tabular}{|c|c|c|c|c|c|}
\hline 0.454 & 0.176 & 0.004 & 0.217 & 0.694 & $0.642-0.747$ \\
\hline 0.587 & 0.054 & 0.116 & 0.077 & 0.725 & $0.681-0.768$ \\
\hline 0.573 & -0.126 & 0.176 & 0.204 & 0.687 & $0.640-0.735$ \\
\hline 0.544 & 0.174 & 0.278 & -0.207 & 0.718 & $0.817-0.876$ \\
\hline 0.767 & 0.168 & -0.025 & -0.027 & 0.847 & $0.817-0.876$ \\
\hline 0.883 & 0.042 & -0.143 & 0.088 & 0.859 & $0.831-0.887$ \\
\hline 0.860 & 0.015 & -0.194 & 0.151 & 0.815 & $0.755-0.854$ \\
\hline 0.937 & 0.065 & -0.175 & 0.022 & 0.869 & $0.840-0.897$ \\
\hline 0.865 & -0.008 & -0.180 & 0.154 & 0.813 & $0.774-0.853$ \\
\hline 0.794 & -0.012 & 0.056 & 0.027 & 0.827 & $0.792-0.862$ \\
\hline 0.799 & -0.008 & 0.024 & 0.037 & 0.820 & $0.783-0.858$ \\
\hline 0.828 & -0.011 & -0.037 & 0.059 & 0.812 & $0.775-0.848$ \\
\hline 0.626 & 0.060 & 0.303 & -0.192 & 0.745 & $0.706-0.784$ \\
\hline 0.621 & 0.138 & 0.283 & -0.205 & 0.779 & $0.743-0.815$ \\
\hline 0.747 & 0.090 & 0.108 & -0.103 & 0.809 & $0.773-0.844$ \\
\hline-0.099 & 0.622 & 0.277 & -0.046 & 0.649 & $0.600-0.697$ \\
\hline 0.151 & 0.758 & -0.029 & -0.071 & 0.782 & $0.764-0.834$ \\
\hline 0.109 & 0.726 & 0.093 & -0.073 & 0.799 & $0.764-0.834$ \\
\hline 0.127 & 0.747 & 0.035 & -0.066 & 0.798 & $0.761-0.835$ \\
\hline 0.028 & 0.736 & 0.001 & 0.102 & 0.778 & $0.739-0.817$ \\
\hline
\end{tabular}


Table 1. Exploratory and confirmatory factor analysis (Continued)

\begin{tabular}{|c|c|c|c|c|c|c|}
\hline \multirow[t]{2}{*}{ Factors and items } & \multicolumn{4}{|c|}{ EFA } & \multicolumn{2}{|r|}{ CFA } \\
\hline & ARE & PR & LC & PE & SFL & $95 \% \mathrm{Cl}$ \\
\hline \multicolumn{7}{|c|}{ Factor 2. Loss of control } \\
\hline $\begin{array}{l}\text { 6. No hago más que pensar en la comida } \\
\text { (I feel like I have food on my mind all the time) }\end{array}$ & -0.045 & 0.675 & 0.138 & 0.112 & 0.753 & $0.712-0.794$ \\
\hline $\begin{array}{l}\text { 7. A menudo me siento culpable cuando deseo ciertas comidas } \\
\text { (I often feel guilty for craving certain foods) }\end{array}$ & 0.110 & 0.710 & -0.074 & 0.101 & 0.765 & $0.721-0.808$ \\
\hline $\begin{array}{l}\text { 8. A veces me encuentro pensativo preocupado con comida (I find myself } \\
\text { preoccupied with food) }\end{array}$ & 0.283 & 0.620 & -0.208 & 0.205 & 0.802 & $0.761-0.842$ \\
\hline
\end{tabular}

Factor 3. Physiological response

11. Se me hace agua la boca cuando pienso en mis comidas favoritas (Thinking \begin{tabular}{lllll|l|l}
-0.226 & 0.322 & 0.635 & 0.085 & 0.621 & $0.578-0.665$
\end{tabular} about my favorite food makes my mouth water)

12. Siento deseos intensos de comer cuando mi estómago está vacío (I crave foods $\quad$\begin{tabular}{ll|l|l|l|l}
-0.179 & 0.102 & 0.826 & 0.030 & 0.671 & $0.632-0.710$
\end{tabular} when my stomach is empty)

13. Siento que mi cuerpo me pidiera ciertas comidas $\quad \begin{array}{lllllll} & 0.119 & 0.159 & 0.497 & 0.088 & 0.724 & 0.680-0.768\end{array}$ (I feel as if my body asks me for certain food)

14. Me da tanta hambre que mi estómago se siente como un pozo sin fondo(I get $\quad \begin{array}{lllllll}0.202 & 0.219 & 0.366 & 0.080 & 0.711 & 0.667-0.754\end{array}$ so hungry that my stomach seems like a bottomless pit)

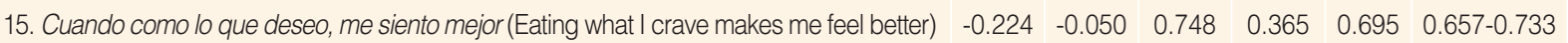

18. Cada vez que deseo comer algo en particular, me pongo a hacer planes para $\quad \begin{array}{lllllll}0.301 & 0.059 & 0.353 & 0.174 & 0.734 & 0.695-0.773\end{array}$ comer (Whenever I have cravings, I find myself making plans to eat)

19. El comer me tranquiliza (Eating calms me down)

\begin{tabular}{lll|l|l|l}
0.208 & -0.216 & 0.357 & 0.578 & 0.734 & $0.695-0.772$
\end{tabular}

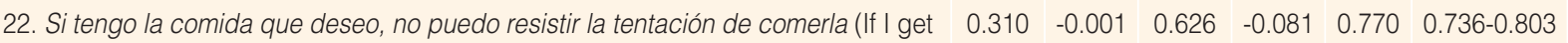
what I am craving I cannot stop myself from eating it)

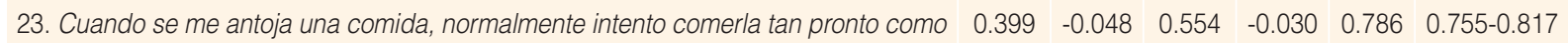
pueda (When I crave certain foods, I usually try to eat them as soon as I can)

24. Comer lo que me apetece mucho me sienta estupendamente (When I eat what I crave I feel great)

\begin{tabular}{l|l|l|l|l|l}
0.099 & -0.170 & 0.719 & 0.192 & 0.740 & $0.706-0.774$
\end{tabular} Factor 4. Positive emotions

9. Como para sentirme mejor (I eat to feel better)

10. Algunas veces, mi vida parece perfecta cuando como lo que me apetece (Sometimes, eating make things seem just perfect)

16. Cuando como lo que deseo me siento menos deprimido (When I satisfy a craving, I feel less depressed)

37. Comer me alivia (When I eat food, I feel comforted)

\begin{tabular}{|c|c|c|c|c|c|}
\hline 0.014 & 0.365 & -0.073 & 0.657 & 0.779 & $0.733-0.824$ \\
\hline-0.197 & 0.365 & 0.218 & 0.596 & 0.718 & $0.673-0.764$ \\
\hline 0.343 & 0.029 & 0.133 & 0.460 & 0.802 & $0.768-0.836$ \\
\hline & & & & & \\
\hline 0.228 & -0.192 & 0.207 & 0.638 & 0.716 & $0.672-0.761$ \\
\hline
\end{tabular}

EFA=exploratory factor analysis, CFA=confirmatory factor analysis, ARE=anticipation and reinforcement for eating, $\mathrm{LC}=$ loss of control, $\mathrm{PR}=$ physiological response, $\mathrm{PE}=$ positive emotions, SFL=standardized factor loading, $\mathrm{Cl}=$ confidence interval.

Values between 0.90 and 0.95 are considered adequate for CFI and TLI and between 0.06-0.08 for RMSEA and SRMR, while values $>0.95$ were considered excellent for CFI and TLI, as values $<0.06$ were for RMSEA and SRMR.

Finally, the regression method was used to extract factor scores and score descriptive statistics and reliability indices (Cronbach's $\alpha$ and Dillon-Goldstein's rho coefficients) from each factor that makes up the
Table 2. Estimated goodness of fitness model statistics

\begin{tabular}{|l|c|c|c|c|c|c|}
\hline$\chi^{2}$ & df & $p$ & CFI & TLI & RMSEA & SRMR \\
\hline 2588.959 & 623 & 0.0001 & 0.889 & 0.882 & 0.055 & 0.051 \\
\hline
\end{tabular}

$\chi^{2}=$ chi-square test for exact fit. EFA=exploratory factor analysis, CFA=confirmatory factor analysis, df=degrees of freedom, CFI=comparative fit index, TLI=Tucker-Lewis index, RMSEA=root mean square error of approximation, SRMR=standardized root mean square residual.

instrument. A coefficient value $>0.80$ indicates a high level of internal consistency. The relationship between 
Table 3. Descriptive statistics, internal consistency and correlations between factors

\begin{tabular}{|c|c|c|c|c|c|c|c|c|}
\hline \multirow[t]{2}{*}{ Factors } & \multicolumn{2}{|c|}{$\begin{array}{l}\text { Descriptive } \\
\text { statistics }\end{array}$} & \multicolumn{2}{|c|}{ Internal consistency } & \multicolumn{4}{|c|}{ Correlations } \\
\hline & Mean & SD & Cronbach's $\alpha$ & Dillon- Goldstein's rho & ARE & LC & PR & PE \\
\hline $\begin{array}{l}\text { Anticipation and } \\
\text { reinforcement for eating }\end{array}$ & 0.000 & 1.155 & 0.960 & 0.965 & & $0.859^{*}$ & $0.854^{*}$ & $0.865^{*}$ \\
\hline Loss of control & 0.000 & 1.115 & 0.920 & 0.935 & $0.842-0.874^{\star *}$ & & $0.819^{*}$ & $0.852^{*}$ \\
\hline Physiological response & 0.000 & 1.201 & 0.913 & 0.929 & $0.837-0.870^{\star \star}$ & $0.798-0.838^{* *}$ & & $0.936^{*}$ \\
\hline Positive emotions & 0.000 & 1.169 & 0.838 & 0.894 & $0.849-0.879^{\star *}$ & $0.835-0.868^{* *}$ & $0.928-0.943^{\star *}$ & \\
\hline
\end{tabular}

$\mathrm{SD}=$ standard deviation; ARE=anticipation and reinforcement for eating; $\mathrm{LC}=$ loss of control; PR=physiological response; PE=positive emotions. ${ }^{*}$ Pearson's correlation. * ${ }^{*} 95 \%$ confidence interval.

domains was assessed with Pearson's correlations; if higher than 0.81 , it was considered excellent, between 0.61 and 0.80 very good, and between 0.41 and 0.60 , good. Of the 1059 participants, $71.86 \%$ (761) were females; mean age was $39.90 \pm 14.97$ years.

\section{Results}

In the factor analysis, a simple adequacy of 0.977 was obtained, and with Bartlett's test of sphericity, $\chi^{2}$ $=31143.93$ and $\mathrm{df}=666$, with $p<0.0001$, which indicates items adequacy for structure detection.

With the Promax analysis, all items obtained weight factors higher than 0.35 and were reorganized differently with regard to the Spanish version, and had therefore the name changed and were redefined as follows (Table 1):

- Factor 1, anticipation and reinforcement for eating: thinking frequently about the food that is craved makes remembering and anticipating the pleasant emotions that are generated after eating, which will reinforce the search for food and its consumption.

- Factor 2, loss of control: the intense desire to consume the food that generates craving will trigger overeating and cause guilt for giving in to it.

- Factor 3, physiological response: craving arises as a physiological response to physical stimuli or evocation of memories related to appetizing food and its consumption.

- Factor 4, positive emotions: the consumption of appetizing food is associated with hedonic states that will magnify the feeling of relief and well-being.

The FCQ-T was observed to explain $52.91 \%$ of variance.

The confirmatory factor analysis was performed using the robust maximum likelihood estimator. The goodness of fit statistics and the information criteria of the estimated model are presented in Table 2. The chi-square test was significant and the robust fit indicators were analyzed: RMSEA and SRMR showed excellent goodness of fit in the structural equation model, whereas a poor value was obtained for CFI and TLI.

The confirmatory factor analysis revealed an adequate standardized factor loading (anticipation and reinforcement for eating $=0.687-0.869$, loss of control $=0.649-0.802$, physiological response $=0.621-0.786$, positive emotions $=0.716-0.802$ ) and all standardized factor loading confidence intervals were significant (Table 1).

Table 3 shows the mean and standard deviation of the scores obtained from the factors. A Cronbach's $\alpha=0.973$ and Dillon-Goldstein's rho $=0.975$ were obtained, indicating that it is reliable, while the values obtained by factors are higher than 0.80 . With the confirmatory factor analysis, correlations between all factors were excellent and positive; all correlation coefficient confidence intervals were statistically significant.

\section{Discussion}

FCQ-T's reliability was found to be consistent with research conducted in America and Europe $(\alpha \geq 0.90)$. Regarding the factorial structure, differences were found in the number of total dimensions, as it has occurred in various validations. ${ }^{16-18}$

Structurally, factor reduction and item regrouping were performed: all 37 items that originally made up the Spanish version were preserved,$^{19}$ but were regrouped in four factors that were consistent with those subtracted in other studies. ${ }^{16-18}$ Item interpretation is influenced by emotional, behavioral, cognitive and contextual-cultural variables, which might explain the rotation of factors. ${ }^{17}$ 
Interestingly, factor disposition in this study was similar to that of the Cuban validation: ${ }^{18}$ in both, the elements that refer to positive reinforcements generated by ingestion are observed in factor 1 .

The data obtained in this research show that there are thoughts related to food that cause pleasant emotions, which motivates overeating. The difference lies in certain items: items 17 ("when I eat what I am craving intensely I feel guilty about myself"), 20 ("I crave foods when I feel bored, angry, or sad"), 21 ("I feel less anxious after I eat") and 22 ("if I get what I am craving I cannot stop myself from eating it") are grouped differently in the Cuban version, ${ }^{18}$ and in this version they have been included in the first factor, which explains that consumption triggers guilt, boredom, anger or sadness for not being able to resist temptation.

Factor 2 was named loss of control, consistent with the Dutch ${ }^{16}$ and the Cuban versions. ${ }^{18}$ In the former, items 2 ("when I crave something, I know I won't be able to stop eating once I start") and 3 ("if I eat what I am craving, I often lose control and eat too much") coincided ${ }^{16}$ whereas in the in Cuban version, items 2 , 3 and 1 ("being with someone who is eating often makes me hungry") ${ }^{18}$ coincide. The other items integrated into this factor explain the intensity of the desire to eat certain type of foods that cause overeating and feelings of guilt. Unlike Rodríguez Martín and Molerio Pérez observations,$^{18}$ loss of control is not due to environmental cues but to intrinsic characteristics of the subject that drive him/her to impulsively consume. ${ }^{19}$

Factor 3 was named "physiological response", based on the conditioned response to hunger, such as salivation when remembering food, feeling of "non-satiety", "being dissatisfied" and a feeling of pleasure when eating. Items 11 ("thinking about my favorite food makes my mouth water"), 13 ("I feel as if my body asks me for certain food") and 14 ("I get so hungry that my stomach seems like a bottomless pit") coincide with factor 5 (craving as a physiological state) of the original, ${ }^{11}$ the Spanish ${ }^{20}$ and the Brazilian versions ${ }^{21}$ and in factor 6 (renamed "hunger") of the German version. ${ }^{17}$

The last factor (factor 4) was named "positive emotions", unlike Rodríguez Martín and Molerio Pérez proposal, ${ }^{18}$ who explain this factor as "eating to regulate emotions or emotional ingestion". However, both factors only coincide in items 19 ("eating calms me down") and 37 ("When I eat food, I feel comforted").
In the present investigation, the referred items were added and other were regrouped (Table 1). Consumption is associated with positive emotions, and the sense of reward is thus magnified.

\section{Acknowledgements}

To the Ministry of Health of Mexico City, especially to Mr. Leopoldo Galván Pérez, responsible for Distant Medicine.

\section{References}

1. Al-Nakeeb $Y$, Lyons M, Dodd LJ, Al-Nuaim A. An investigation into the lifestyle, health habits and risk factors of young adults. Int J Environ Res Public Health. 2015;12:4380-4394.

2. El-Kassas G, Ziade F. Exploration of the dietary and lifestyle behaviors and weight status and their self-perceptions among health sciences university students in North Lebanon. BioMed Rest Int. 2016; 2016:9762396.

3. Berridge KC, Ho CY, Richard JM, DiFeliceantonio AG. The tempted brain eats: pleasure and desire circuits in obesity and eating disorders. Brain Res. 2010;1350:43-64

4. Frankort A, Roefs A, Siep N, Roebroeck A, Havermans R, Jansen A. The craving stops before you feel it: neural correlates of chocolate craving during cue exposure with response prevention. Cereb Cortex. 2014;24:1589-1600

5. Mühlberg C, Mathar D, Villringer A, Horstmann A, Neumann J. Stopping at the sight of food: how the gender and obesity impact on response inhibition. Appetite. 2016;107:663-676.

6. Iani L, Barbaranelli C, Lombardo C. Cross-validation of the reduced form of the Food Craving Questionnaire-Trait using confirmatory factor analysis. Front Psychol. 2015;6:433.

7. Pelchat ML. Of human bondage: Food craving, obsession, compulsion, and addiction. Physiol Behav. 2002;76:347-352.

8. Tiggemann M, Kemps E. The phenomenology of food cravings: the role of mental imagery. Appetite. 2005;45:305-313.

9. Pelchat ML, Johnson A, Chan R, Valdez J, Ragland JD. Images of desire: food-craving activation during fMRI. Neuroimage. 2004;23: 1486-1493.

10. Potenza MN, Grilo CM. How relevant is food craving to obesity and its treatment? Front Psychiatry. 2014;5:164.

11. Cepeda-Benito A, Gleaves DH, Williams TL, Erath SA. The development and validation of the state and trait food-cravings questionnaires. Behav Res Ther. 2000;31:151-173.

12. Avitia GC, Loya-Méndez Y, Portillo-Reyes V, Reyes-Leal G, Capps Iv JW. Cravings, sugar and fat consumption as determinant factors of obesity in young adults in Juarez City. Nutr Hosp. 2018;35:833-840.

13. psych. Procedures for personality and psychological research [En línea] EEUU: Northwestern University; 2017.

14. Rosseel $Y$. lavaan: an R package for structural equation modeling. J Stat Software. 2012;48:1-36.

15. Kaiser HF. An index of factorial simplicity. Psychometrika. 1974:39:31-36.

16. Nijs I, Franken I, Muris P. The modified Trait and State Food-Cravings Questionnaires: development and validation of a general index of food craving. Appetite. 2007;:49:38-46.

17. Meule A, Lutz A, Vögele $C$, Küber A. Food cravings discriminate differentially between successful and unsuccessful dieters and non-dieters. Validation of the Food Cravings Questionnaires in German. Appetite. 2012;58:88-97.

18. Rodríguez-Martín, BC, Molerio-Pérez O. Exploring the factor structure of the Food Cravings Questionnaire-Trait in Cuban adults. Front Psychology. 2014;5:1-12.

19. Veilleux JC, Hill MA, Skinner KD, Pollert GA, Baker DE, Spero KD. The dynamics of persisting through distress: development of a momentary distress intolerance scale using ecological momentary assessment. Paschoal Asses. 2018;30:1468-1478.

20. Cepeda-Benito A, Gleaves DH, Fernández MC, Vila J, Williams TL, Reynoso J. The development and validation of Spanish versions of the state and trait food cravings questionnaires. Behav Res The. 2000;38:1125-1138.

21. Queiroz-De Medeiros AC, Campos-Pedrosa LF, Hutz CS, Yamamoto ME. Brazilian version of food cravings questionnaires: psychometric properties and sex differences. Appetite. 2016;105:328-333. 